\title{
Experiments with the long-term rumen simulation technique (Rusitec); use of soluble food and an inert solid matrix
}

\author{
BY J. W. CZERKAWSKI AND GRACE BRECKENRIDGE \\ The Hannah Research Institute, Ayr, Scotland KA6 ${ }_{5} H L$
}

(Received 2 January 1979 - Accepted 26 February 1979)

1. The role of soluble nutrients and of the solid matrix in rumen fermentation was investigated in some detail, and experiments designed to explore the possibility of using a balanced soluble diet and an inert solid matrix, are described.

2. The use of a balanced soluble substrate as the only source of nutrients in the presence of an inert solid phase in the reaction vessels results in vigorous fermentation but is accompanied by disappearance of protozoa from the effluent.

3. In the absence of digestible solid phase, the rate of fermentation and the fermentation pattern depends mainly on the amount and type of nutrients supplied and to a smaller extent on the dilution rate, the variations being greatest at low dilution rates.

4. The solid matrix in the form of wood shavings or the residue remaining after prolonged digestion of hay could sequestrate micro-organisms and could be used as solid phase, but the defined mixture of soluble substrates used resulted in somewhat abnormal fermentation compared with fermentation obtained with solid food.

5. When the solid food included some hay extract and when the dilution rate was not too great a reduced output of protozoa could be maintained. At high dilution rate the outflow of protozoa was negligible and yet considerable numbers of protozoa were found in the solid matrix and associated liquid.

6. A three-compartment model was developed to describe the flow of liquid and microbial matter within the simplified system.

There is little doubt that the successful simulation of rumen fermentation with the Rumen Simulation Technique (Rusitec) is mainly due to the presence in the reaction mixture of a semi-solid matrix of undigested food material. If it could be shown that the microbial population of the rumen could be maintained on a properly balanced soluble food, then the presence of a solid inert matrix may be sufficient to simulate rumen fermentation. However, it is not known whether the beneficial effect of using roughage food is due to specific nutrients supplied by such food or due to provision of a solid matrix, to which microorganisms may be attached. In other words, is it possible to replace the solid food by a suitable indigestible matrix, supplement this with soluble food and still obtain results that would resemble those obtained in vivo? The experiments in this series were attempts to take the supplementation to its logical conclusion, by using a virtually undigestible roughage and a nutritionally balanced, but soluble concentrate supplement.

In the earlier paper (Czerkawski \& Breckenridge, 1979) the solid food was supplemented with soluble food that was infused continuously or introduced with the daily ration of solid food. Attempts were also made to see what happens to the roughage and concentrate components of the solid food and if the location of these components within the reaction vessels would influence the fermentation.

The rumen micro-organisms show certain specificity in attaching themselves to the solid substrate (e.g. see Latham et al. 1978; Orpin \& Letcher, 1978) and we did not consider it advantageous to use any wholly artificial matrix, like nylon or polyethylene fibre. Preliminary experiments showed that most of the digestible matter in the solid food is removed during the first day of incubation ( $70-80 \%$ of digestible material), that a smaller amount is removed on the second day and that the roughage contains a proportion of material that is virtually 
indigestible. This was the material that was chosen to serve as an inert matrix, but the possibility of using another heavily lignified material (i.e. wood) was also considered.

\section{EXPERIMENTAL}

\section{Methods and materials}

The apparatus used was as described earlier (Czerkawski \& Breckenridge, 1977). The inocula for starting the experiments were obtained from sheep on a diet of hay and small amounts $(20 \%)$ of concentrate (goat mix). The analytical procedures were the same as described in the earlier papers (Czerkawski \& Breckenridge, 1977, 1979).

\section{Experimental procedures}

Expt I. Four vessels, nominal volume up to overflow $\mathrm{I} \cdot 01$, were used in this experiment. On day I, apart from the rumen fluid from sheep given hay and goat mix, each vessel contained two bags of strained rumen solids $(80 \mathrm{~g})$ and one bag of hay ( $10 \mathrm{~g})$. The bags in the vessels were replaced daily so that after $4 \mathrm{~d}$, vessel no. I contained three bags of hay residue, vessel no. 2 contained two bags of hay and one bag of wood shavings, vessel no. 3 contained one bag of hay and two bags of wood shavings and vessel no. 4 contained three bags of wood shavings. From day 4 until the end of the experiment the vessels were not opened. The food was dissolved in the artificial saliva (McDougall, I948) and infused continuously into each vessel. From days $I_{\text {to }}$ is the nominal dilution rate was $0.9 / \mathrm{d}$ and this was reduced to $0.45 / \mathrm{d}$ during days $16-22$ but the food input was kept constant by doubling the concentration of soluble food in the infusate.

During the first part of the experiment (days I-I5), the soluble food contained the following $(\mathrm{g} / 1$ artificial saliva): carbohydrate 12.0 , organic acids 0.73 , protein $2 \cdot 0$, lipid 0.75 , salts 1.22 and trace compounds 0.025 . The carbohydrates consisted of the following $(\mathrm{g} / \mathrm{l})$ : carboxymethylcellulose $2 \cdot 4$, cellobiose $0 \cdot \mathrm{I}$, maltose $\mathrm{I} \cdot 8$, glucose $3 \cdot 0$, xylose $2 \cdot 4$, arabinose 0.6 , galactose 0.4 , rhamnose 0.2 , galacturonic acid 0.5 and raffinose 0.6 . The organic acids included (mg/l): citric 290 , malic 210 , lactic 80 , succinic 70 , oxalic 40 and malonic 40 . The nitrogen was supplied by inclusion of soluble casein at $2.0 \mathrm{~g} / \mathrm{l}$ and the lipid was in the form of linseed-oil fatty acids and glycerol at 0.6 and $0.15 \mathrm{~g} / 1$ respectively. The composition of salts was as follows $(\mathrm{mg} / \mathrm{l})$ : potassium acetate $602, \mathrm{CaHPO}_{4} \cdot 2 \mathrm{H}_{2} \mathrm{O} 2 \mathrm{I} 5$, $\mathrm{NaCl} 65$ and $\mathrm{MgSO}_{4} 355$. This provided approximately the following (mg/l): potassium 240, calcium 56, sodium 25 , magnesium 35 , phosphorus $40, \mathrm{~S} 40, \mathrm{Cl} 70$. Finally, the soluble food contained the following trace compounds $(\mathrm{mg} / \mathrm{l}): \mathrm{FePO}_{4}, \mathrm{MnSO}_{4}, \mathrm{CuSO}_{4} \cdot \mathrm{H}_{2} \mathrm{O}$, $\mathrm{ZnSO}_{4}$ and $\mathrm{H}_{3} \mathrm{BO}_{3}$ to give iron $2 \cdot 5$, manganese $3 \cdot 0$, copper 0.1 , zinc $\mathrm{I} \cdot 0$ and boron $0.1 \mathrm{mg} / \mathrm{l}$.

The nutrients listed previously were mixed well and weighed in portions that would be sufficient for four vessels for I $\mathrm{d}$. These portions were dissolved in $4^{\circ} \mathrm{O} /$ artificial saliva I d before use. Linseed-oil fatty acids, glycerol and lactic acid were added as an emulsion in $20 \mathrm{ml}$ Tween $80(200 \mathrm{ml} / \mathrm{l})$. Finally, the $\mathrm{pH}$ of the solution was adjusted to 9.3 with strong sodium hydroxide solution ( $\mathrm{IO} \mathrm{M}$ ). During days $\mathrm{I}$ 6-22 the same amounts of nutrients were dissolved in 2.01 artificial saliva to give double the concentration.

On day 16 of the experiment an inoculum of protozoa was prepared from 21 strained rumen contents obtained from the donor sheep (Czerkawski, 1976) to give a suspension of protozoa in artificial saliva, containing $4 \times 10^{6}$ protozoa $/ \mathrm{ml}$ in $250 \mathrm{ml}(8 \%$ holotrichs $)$. This was injected into the vessels to give a protozoal concentration of approximately $2.4 \times 10^{5} / \mathrm{ml}$ reaction mixture.

Samples of gas and effluent were taken daily for analysis. As described previously, the head-space gases in the reaction vessels and in the collection flasks were swept into the gas- 
collection bags with $\mathrm{I} \cdot 0 \mathrm{l}$ carbon dioxide- $\mathrm{N}_{2}(5: 100)$ and the effluent was collected in $\mathrm{I} \cdot 0 \mathrm{I}$ flasks containing $10 \mathrm{ml}$ one-fifth saturated mercuric chloride.

Expt 2. Two vessels (nominal volume $\mathrm{I} \cdot \mathrm{O}$ l) were used and the solid matrix was provided by the undigested residue of three bags of $10 \mathrm{~g}$ extracted hay. The solid rumen inoculum and hay were replaced by the extracted hay so that on day 4 of the experiment each vessel contained the residue of extracted hay only. As before, some analyses were made daily. No attempt was made to bulk or to vary the conditions before day 15 of the experiment to allow for complete removal of the digestible part of the solid matrix. The diet consisted of the following $(\mathrm{g} / 1)$ : carbohydrate $12 \cdot 0$, protein $2 \cdot 0$, dried hay extract 0.5 , salts $\mathrm{I} \cdot 4$, trace compounds 0.024 during the first $30 \mathrm{~d}$ of the experiment. From day $3 \mathrm{I}$ onwards the concentration of the constituents infused into vessel no. I was doubled and the concentration of constituents infused into vessel no. 2 was halved. The composition of salts and trace compounds was the same as in the previous experiment. The carbohydrate mixture was simpler than in Expt $\mathrm{I}$; it consisted of $(\mathrm{g} / \mathrm{l})$ glucose 5, xylose 2, sucrose 2, arabinose $\mathrm{I}$, galactose I, pectin I. The hay extract was prepared by extracting hay $(300 \mathrm{~g})$ with equal volumes of boiling water, o.or $\mathrm{M}-\mathrm{NaOH}, \mathrm{o} . \mathrm{Or} \mathrm{M}$-hydrochloric acid and again with boiling water, pooling the extracts and freeze-drying. This yielded $190 \mathrm{~g}$ dried residual fibre and $50 \mathrm{~g}$ extract. The powder contained $(\mathrm{g} / \mathrm{kg}) 30$ carbohydrate, $32 \mathrm{~N}, 31$ ash and 4 lipid. The food constituents were kept as weighed solid mixtures and were dissolved in artificial saliva ( $\mathrm{pH} 9.5$ ) not more than $\mathrm{I} d$ before infusion. The $\mathrm{pH}$ of the reaction mixture was kept within the range 6.9-7. I throughout the experiment by adding small amounts of Io $\mathrm{M}-\mathrm{NaOH}$ solution to the infusion mixture in the initial stages $(5 \mathrm{ml} / 1$ on day 3 decreasing to approximately $\mathrm{I} \mathrm{ml} / 1$ on day 8 ); no additions were necessary from days 9 to 30 . During days $3 \mathrm{I}-38$, it was necessary to add $10 \mathrm{M}-\mathrm{NaOH}$ in vessels with low dilution rate and $6 \mathrm{M}-\mathrm{HCl}$ in the vessel with a high dilution rate, both at $5 \mathrm{ml} / 1$.

The nominal dilution rate in both vessels during days $I-30$ was $0.85 / d$ and on day $3 I$ this was halved in one vessel and doubled in the other vessel.

Before the start of the experiment, the perforated moving cages in both vessels were fitted with approximately $2 \mathrm{~m}$ of silicone tubing ( $\mathrm{mm} \mathrm{i.d.)} \mathrm{with} \mathrm{inlet} \mathrm{and} \mathrm{outlet} \mathrm{in} \mathrm{the} \mathrm{lid}$ of the vessels. Oxygen was pumped in through the tube during days I5-2I in vessel no. 3 and during days $22-30$ in vessel no. 2 at a nominal rate of $100 \mathrm{ml} / \mathrm{d}$ and the gases emerging at the outlet were collected and analysed. The emerging gas contained methane $(30-60 \mathrm{ml} / \mathrm{d})$ and $\mathrm{CO}_{2}(70-150 \mathrm{ml} / \mathrm{d})$ and these volumes were added to the volumes determined in the gas-collecting bags. The emerging gas also contained variable amounts of $\mathrm{O}_{2}$ which were subtracted from the $\mathrm{O}_{2}$ infused to obtain the $\mathrm{O}_{2}$ uptake by the reaction mixture. The mean uptake was $86 \mathrm{ml} / \mathrm{d}$.

Expt 3. Modified apparatus with two vessels was used in this experiment (volume up to overflow $840 \mathrm{ml}$ ). As in the previous experiments the solid matrix consisted of extracted hay which was left inside the vessels throughout the experiment. The soluble food was the same as in Expt 2, but the method of administration was different. In vessel no. I, the food was dissolved in artificial saliva and infused continuously to deliver nominally $9.5 \mathrm{~g} / \mathrm{d}$. In vessel no. 2, the artificial saliva was infused at the same rate, but the food $(9.5 \mathrm{~g})$ was dissolved in $60 \mathrm{ml}$ water and injected into the vessel in the morning. A rapid churning of the contents freed much of the trapped gas and lowered the level of liquid in the vessel, so that the food solution could be injected without overflowing. The daily samples were bulked during days I 1-I6 and days 17-22 and kept for analyses. At the end of experiment, the vessels were opened, the bags with solid matrix were allowed to drain into the vessels and the solids were washed as before. The distribution of liquid and various substances in the liquid reaction mixture, the washings and the washed solids was determined. 


\section{RESULTS}

Expt I. Use of soluble food, wood or indigestible hay matrix

Apart from the initial period of approximately $10 \mathrm{~d}$, the output of gases and volatile fatty acids was very similar in all vessels. In general, the output of end-products of fermentation declined during days 4-10 and the rate of this decrease was greatest when wood shavings were used and slowest with hay residues only. In all vessels, the output of end-products was reasonably steady during period no. 2, days $12-15$ (Table I) and in general was slightly lower than during period no. I (days $7-\mathrm{II}$ ). The fermentation favoured acetic and butyric acids rather than propionic acid, although there was an increase in the production of isovaleric acid. During period no. 3 (days I5-24) the dilution rate used was considerably smaller than in the first part of the experiment and yet the output of end-products was not very different from the output in the first part of the experiment. Clearly, when soluble food was used in this experiment, together with an inert solid matrix, the rate of output of endproducts was not markedly affected by the dilution rate. We have seen in other experiments in this series, that the dilution rate may have greater influence on the fermentation when digestible solid food is used (Czerkawski \& Breckenridge, 1977, 1979).

It was possible to maintain a good bacterial population throughout the experiment and although the reaction mixture lost most of its green colour, it had the characteristic rumen smell. The bacterial concentration in the effluent was approximately $2 \times 10^{10} / \mathrm{ml}$ up to day 8 and then increased to approximately $6 \times 10^{10} / \mathrm{ml}$ until day $\mathrm{I} 6$. It remained near this value until day 19 , even though the dilution rate had been halved. The bacterial numbers increased after day 19 to approximately $9 \times 10^{10} / \mathrm{ml}$. The increases in bacterial numbers on days 8 and I9 coincided with elimination of protozoa from the effluent. After day 4, the protozoal concentrations in the effluents decreased exponentially from a mean value of approximately $4 \times 10^{4} / \mathrm{ml}$ and no protozoa could be seen in the effluent from any vessels after day 10 . The specific rates of disappearance of protozoa increased with the proportion of wood shavings in the matrix $(0.4,0.6,0.8$ and $\mathrm{I} \cdot 2 / \mathrm{d}$ in the effluents from vessels nos. $\mathrm{I}, 2,3$ and 4 respectively). After reinoculation with protozoa on day $5_{5}$, the protozoal concentrations declined rapidly in all vessels from $7 \times 10^{4} / \mathrm{ml}$ on day 16 at a specific rate of $1 \cdot 3 /$ d, i.e. similar to the rate in the vessel with wood shavings only during the first part of the experiment. It must be concluded, therefore, that provision of a solid matrix is not sufficient to ensure measurable output of protozoa in the effluent. In the first part of the experiment the output of protozoa in effluent was prolonged in proportion to the hay content of the solid matrix, while in the second part of the experiment, when presumably most of the potential nutrients had been removed from hay, the protozoa disappeared equally rapidly in all vessels.

The outputs of substances other than the end-products of fermentation are summarized in Table 2. The only source of $\mathrm{N}$ in the experiment was casein and the results show that the mean recovery of $\mathrm{N}$ was $98 \%$. On the other hand the recovery of lipid was very low $(46 \%)$ whether determined as crude extracted lipid or as fatty acid by direct esterification of the freeze-dried effluent. The recovered lipid was very saturated (approximately $730 \mathrm{mg}$ stearic acid/g), while the dietary lipid contained nearly $720 \mathrm{mg}$ linoleic acid $/ \mathrm{g}$. This indicated that biohydrogenation of fatty acids occurred, but it would be difficult to give a quantitative account of this process. The output of ammonia- $\mathrm{N}$ showed that $\mathrm{N}$ was not limiting and the concentrations of soluble carbobydrate in the effluent were consistent with metabolism of a large proportion of the dietary carbohydrate $(93 \%)$. The particulate dry matter (DM) output in the effluent was greater than one would expect from previous experiments. It contained $(\mathrm{g} / \mathrm{kg})$ approximately 90 carbohydrate and 230 true protein ( $\alpha$-amino group $\times$ I02) (relatively low value), but the diaminopimelic acid (DAP) content was somewhat larger ( $3 \cdot 3 \mathrm{mg} / \mathrm{g} \mathrm{DM})$ than determined previously $(3.0 \mathrm{mg} / \mathrm{g})$. 
Table I. Output (mmol/d) of gases and volatile fatty acids $(V F A)$ with the Rumen Simulation Technique (Rusitec) using soluble food and a matrix of undigested residue from hay (vessel no. I) or wood shavings (vessel no. 4) or mixtures of these substances (hay-wood, 2: I in vessel no. 2 and $\mathrm{I}: 2$ in vessel no. 3)

(The results for each vessel were calculated as means of daily determinations for days 7-11, 12-15 and 19-24. Since there was no difference due to the composition of the solid matrix (particularly during periods nos. 2 and 3) the results are given as means with their standard errors for the four vessels)

\begin{tabular}{|c|c|c|c|c|c|c|}
\hline \multirow[t]{2}{*}{$\begin{array}{c}\text { Period no. ... } \\
\text { Days of experiment }\end{array}$} & \multicolumn{2}{|c|}{$\underset{7-1 I}{I}$} & \multicolumn{2}{|c|}{$\stackrel{2}{12-15}$} & \multicolumn{2}{|c|}{$\begin{array}{c}3 \\
19-24\end{array}$} \\
\hline & Mean & $\mathrm{SE}$ & Mean & SE & Mean & SE \\
\hline $\begin{array}{l}\text { Nominal dilution } \\
\text { rate/d }\end{array}$ & \multicolumn{2}{|c|}{0.83} & \multicolumn{2}{|c|}{0.86} & \multicolumn{2}{|c|}{0.43} \\
\hline \multicolumn{7}{|l|}{ Gases } \\
\hline Methane & $22 \cdot 3$ & 0.8 & $22 \cdot 3$ & 0.3 & $23 \cdot 1$ & $0 \cdot 3$ \\
\hline Carbon dioxide & 53.3 & $1 \cdot 2$ & $53 \cdot 4$ & 0.5 & 50.9 & 0.4 \\
\hline \multicolumn{7}{|l|}{ VFA } \\
\hline Lactic acid & 0.31 & 0.02 & 0.14 & 0.02 & 0.23 & 0.01 \\
\hline Acetic* & $43^{6} 6$ & 1.8 & $39 \cdot 6^{\circ}$ & 0.8 & $40 \cdot 5$ & $1 \cdot 2$ \\
\hline Propionic & $9 \cdot 0$ & 0.7 & $7 \cdot 9$ & 0.4 & 5.8 & 0.6 \\
\hline Butyric & 12.8 & 0.8 & $12 \cdot 0$ & 0.9 & $12 \cdot 8$ & 0.3 \\
\hline Isovaleric & $2 \cdot 5$ & 0.6 & 3.9 & 0.4 & $3 \cdot 0$ & $0 . \mathrm{I}$ \\
\hline Valeric & $1 \cdot 7$ & 0.3 & $\mathrm{I} \cdot 3$ & 0.1 & $\mathrm{I} .5$ & $0 . I$ \\
\hline Hexanoic & 1.9 & 0.2 & $2 \cdot \mathrm{I}$ & 0.4 & $2 \cdot 2$ & 0.2 \\
\hline
\end{tabular}

* This value includes $5.1,5.3$ and $5.3 \mathrm{mmol}$ acetic acid infused daily in soluble food during periods nos. I, 2 and 3 respectively.

Table 2. Output of substances in the effiuent during infusion of soluble food into reaction vessels containing a matrix of digested hay and wood shavings

(The results are means with their standard errors for all four vessels)

Period no. ...
Days of experiment

Effluent particulate

matter

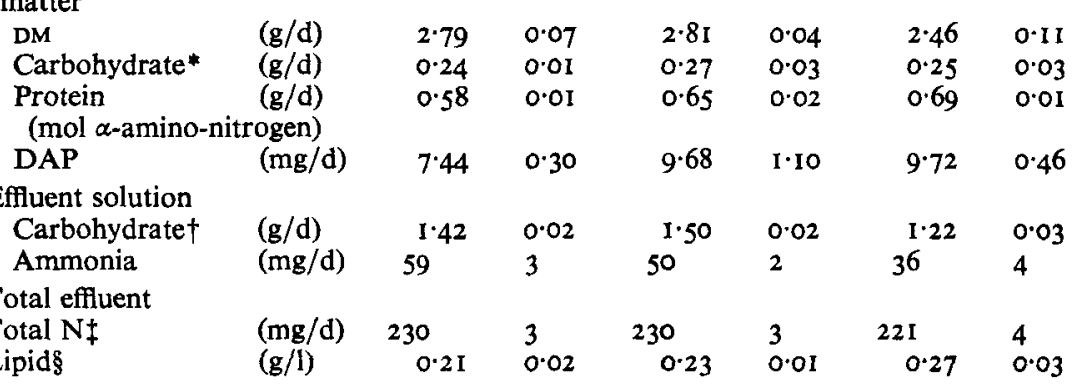



DAP, diaminopimelic acid; DM, dry matter. 


\section{J. W. Czerkawski AND Grace Breckenridge}

Direct bacterial counts in this and in the other experiments with Rusitec, and the comparison with the determination of DAP showed that in most experiments there were approximately $9 \times 10^{12}$ bacteria $/ \mathrm{mg} \mathrm{DAP}$ and that in the present experiment the number of countable bacteria was lower $\left(5 \times 10^{12}\right.$ bacteria $\left./ \mathrm{mg} \mathrm{DAP}\right)$. This suggests that in this experiment a factor of $3.0 \mathrm{mg} / \mathrm{g}$ to convert DAP to bacterial DM might not apply. A better value might be $3 \times \frac{8}{5}=5.4 \mathrm{mg} \mathrm{DAP} / \mathrm{g}$. We hoped that with the simple system used in Expt $\mathrm{I}$, in the absence of protozoa, the bacterial output would be simply given as the particulate DM in the effluent. This is not so and it would appear that of the particulate matter recovered in the effluent, only approximately $600-700 \mathrm{~g} / \mathrm{kg}$ might be bacterial, and that the rest of the particulate $\mathrm{DM}$ in the effluent might be precipitated and therefore modified food (approximately $8 \%$ of food infused).

At the end of Expt I the solid matrix was removed from the vessels, washed and analysed (see Table 3). During the course of the experiment $720-770 \mathrm{~g} \mathrm{DM} / \mathrm{kg}$ in hay disappeared, while the DM of wood shavings increased. Between 680 and $740 \mathrm{~g}$ cellulose $/ \mathrm{kg}$ in hay disappeared, while the digestibility of cellulose in wood shavings was negligibly small $(0.0 \mathrm{I}-0.06)$. Both the undigested residues of hay and wood shavings tended to accumulate lipid and bacterial matter. The hay and wood residues contained 80 and $50 \mathrm{~g}$ lipid $/ \mathrm{kg}$ respectively. The bacterial matter content of hay residue $(100 \mathrm{~g} / \mathrm{kg})$ was considerably greater than the bacterial matter content of residual wood shavings $(30 \mathrm{~g} / \mathrm{kg})$. The value of $100 \mathrm{~g}$ bacterial matter $/ \mathrm{kg}$ in undigested residue of hay compares favourably with the range of $120-150 \mathrm{~g}$ total microbial matter $/ \mathrm{kg}$ in the residue (bacteria + protozoa) in all Rusitec experiments. Clearly the microbiota tended to be associated more with the natural substrate (indigestible hay) than with wood.

It can be shown that the total input of lipid during days 4-24 was approximately $9 \cdot 8 \mathrm{~g}$ and only approximately $4.5 \mathrm{~g}$ of this was recovered in the effluent. The accumulation of lipid in the solid matrix $(0.6-\mathrm{I} \cdot 5 \mathrm{~g})$ accounts for some of the missing lipid, but still leaves $4.2 \mathrm{~g}$ unaccounted for. This lipid, approximately $200 \mathrm{mg} / \mathrm{d}$, would be unlikely to be metabolized under anaerobic conditions. Approximate calculations show that the inside of the reaction vessel, together with the moving cage and three nylon-gauze bags offers a surface area of approximately $0.5 \mathrm{~m}^{2}$. If the unaccounted lipid $\left(4 \mathrm{~g}\right.$ or $\left.5 \times 1 \mathrm{I}^{-6} \mathrm{~m}^{3}\right)$ is spread on this area, it would produce a lipid layer only $0.01 \mathrm{~mm}$ thick. This would be hardly noticeable.

\section{Expt 2. Use of soluble food: undigestible hay matrix}

The results are summarized in Tables 4 and 5 . The inputs of nutrients were similar during all periods, even though the dilution rates ranged from approximately 0.4 to $\mathrm{I} \cdot 7 / \mathrm{d}$. In agreement with results reported previously (Czerkawski \& Breckenridge, 1977), methane production was lower at very low and very high dilution rates. In general, the output of volatile fatty acids was depressed at low dilution rate. There was little or no effect when the reaction mixtures were perfused with $\mathrm{O}_{2}$ gas.

The composition of volatile fatty acids produced was not altered by perfusion with $\mathrm{O}_{2}$, but there was a marked effect of dilution rate (see Table 5). The molar proportions of acetate increased and proportions of butyrate and valerate decreased with increasing dilution rate. Neither the perfusion with $\mathrm{O}_{2}$ nor increased dilution rate had any marked effect on the composition of particulate DM. However, low dilution rate tended to increase the proportion of lipid. Most of the lipid in the effluent particulate matter must have been synthesized de novo because the hay extract ( $40 \mathrm{~g}$ lipid $/ \mathrm{kg}$ ) contributed only approximately II-I $2 \mathrm{mg} \mathrm{lipid} / \mathrm{d}$ in each vessel, compared with an output of $140-240 \mathrm{mg} / \mathrm{d}$.

The distribution of DAP between particulate matter and solution favoured the particulate matter, but the amount of soluble DAP increased from $30 \mathrm{~g} / \mathrm{kg}$ at the highest dilution rate to $80 \mathrm{~g} / \mathrm{kg}$ at the lowest dilution rate. This is consistent with increased microbial 
Table 3. Analyses of the solid matrix of hay and wood shavings after $24 d$ of incubation in Rumen Simulation Technique (Rusitec) supplied with soluble food

Vessel no.

1
25.8
9.1
2.1
0.0
0.0
0.0

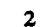

3

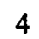

Input at the start

of experiment $(g)$

Hay: DM

Wood: DM

Cellulose Total lipid

Cellulose Total lipid

Solid residue after $24 \mathrm{~d}$ of experiment (g)

Cellulose

Total lipid

Wood: DM Bacterial DM*

$\begin{array}{cc}7.3 & 5.7 \\ 2.4 & 1.7 \\ 0.6 & 0.4 \\ 0.8 & 0.6 \\ 0.0 & 10.3 \\ 0.0 & 6.5 \\ 0.0 & 0.5 \\ 0.0 & 0.4 \\ & \\ 0.77 & 0.73 \\ 0.74 & 0.72 \\ - & 0 \\ - & 0.01\end{array}$

$17 \cdot 2$
$6 \cdot 1$
$1 \cdot 4$
$9 \cdot 2$
$6 \cdot 6$
$0 \cdot 1$

$\begin{array}{rr}8.6 & 0.0 \\ 3.0 & 0.0 \\ 0.7 & 0.0 \\ 18.4 & 27.6 \\ 13.2 & 19.8 \\ 0.2 & 0.3\end{array}$

Cellulose

Total lipid

Bacterial DM*

Proportions digested

Hay: DM†

Wood: DMt Cellulose

Cellulose

-

DM, dry matter; DAP, diaminopimelic acid.

* Bacterial DM was calculated from DAP content by dividing by 5.4 rather than 3.0 (see p. 234).

$\uparrow$ Calculated after subtracting the bacterial DM and the lipid.

Table 4. Fermentation of soluble food in Rumen Simulation Technique (Rusitec) in the presence of a solid matrix of undigested hay residues; effect of perfusion with $\mathrm{O}_{2}$ and of changes in the nominal dilution rate

\begin{tabular}{|c|c|c|c|c|}
\hline \multirow[t]{2}{*}{ Days of experiment } & \multicolumn{2}{|c|}{$16-30$} & \multicolumn{2}{|c|}{$33-38$} \\
\hline & $\underset{\text { (control) }}{\mathrm{A}}$ & $\underset{\text { (oxygen) }}{\mathrm{B}}$ & Vessel I & Vessel 2 \\
\hline $\begin{array}{l}\text { Nominal dilution rate } / \mathrm{d} \\
\text { Inputs }(\mathrm{g} / \mathrm{d})\end{array}$ & 0.85 & 0.88 & 0.42 & $1 \cdot 69$ \\
\hline Carbohydrate & $10 \cdot 10$ & 10.57 & 10.05 & $10 \cdot 16$ \\
\hline Casein & $1 \cdot 53$ & $1 \cdot 60$ & $1 \cdot 53$ & $I \cdot 54$ \\
\hline Hay extract & 0.29 & 0.30 & 0.29 & 0.30 \\
\hline Total & $I I \cdot 92$ & $12 \cdot 47$ & I I 87 & 12.00 \\
\hline $\begin{array}{l}\text { Outputs } \\
\text { End-products (mmol/d) }\end{array}$ & & & & \\
\hline $\mathrm{CH}_{4}$ & $28 \cdot 6$ & $29 \cdot 3$ & 20.9 & $22 \cdot 0$ \\
\hline $\begin{array}{l}\mathrm{CO}_{2} \\
\mathrm{VFA}\end{array}$ & $\begin{array}{l}79 \cdot 1 \\
87 \cdot 2\end{array}$ & $\begin{array}{l}79 \cdot 9 \\
93 \cdot 3\end{array}$ & $\begin{array}{l}48 \cdot 6 \\
65 \cdot 3\end{array}$ & $\begin{array}{l}6 I \cdot 8 \\
92 \cdot 6\end{array}$ \\
\hline Particulate DM (g/d) & $2 \cdot 23$ & $2 \cdot 32$ & $I \cdot 90$ & $2 \cdot 34$ \\
\hline $\begin{array}{l}\text { Carbohydrate + protein in } \\
\text { solution }(g / d)\end{array}$ & 0.08 & 0.07 & 0.08 & 0.09 \\
\hline Output (unit food organic $\mathrm{m}$ & tilized) & & & \\
\hline Methane & $2 \cdot 38$ & $2 \cdot 33$ & $I \cdot 75$ & $1 \cdot 82$ \\
\hline VFA (mol/kg) & $7 \cdot 27$ & $7 \cdot 43$ & $5 \cdot 47$ & 7.68 \\
\hline Microbial DM $(\mathrm{g} / \mathrm{kg})$ & 186.0 & 184.7 & $159 \cdot \mathrm{I}$ & $194 \cdot 0$ \\
\hline
\end{tabular}

A, mean values for vessel no. I, days I6-20 and vessel no. 2, days 26-30; B, mean values for vessel no. I, days $26-30$ and vessel no. 2, days $16-20$; DM, dry matter; VFA, volatile fatty acids. 
Table 5. Composition of products during fermentation of soluble food in Rumen Simulation Technique (Rusitec) in the presence of a matrix of undigested hay residues

\begin{tabular}{|c|c|c|c|c|}
\hline \multirow[t]{2}{*}{ Days of experiment $\ldots$} & \multicolumn{2}{|c|}{$16-30$} & \multicolumn{2}{|c|}{$33-38$} \\
\hline & $\begin{array}{c}\text { A } \\
\text { (control) }\end{array}$ & $\begin{array}{c}\text { B } \\
\text { (oxygen) }\end{array}$ & Vessel I & Vessel 2 \\
\hline \multicolumn{5}{|c|}{ Volatile fatty acids $(\mathrm{mol} / \mathrm{l} 00 \mathrm{~mol})$} \\
\hline Acetate & $67 \cdot 4$ & $69 \cdot 0$ & $61 \cdot 6$ & $75 \cdot 7$ \\
\hline Propionate & $6 \cdot I$ & $6 \cdot 2$ & $7 \cdot 4$ & $8 \cdot 5$ \\
\hline Butyrate & $16 \cdot 6$ & $14 \cdot 9$ & $21 \cdot 7$ & $9 \cdot 0$ \\
\hline $\mathrm{C}_{5}$-acid & $6 \cdot I$ & $5 \cdot 8$ & $7 \cdot 7$ & $3 \cdot 5$ \\
\hline $\mathrm{C}_{\mathrm{B}^{-} \text {-acid }}$ & $4 \cdot 0$ & $4 \cdot I$ & $5 \cdot 7$ & $3 \cdot 2$ \\
\hline \multicolumn{5}{|c|}{ Particulate dry matter $(\mathrm{g} / \mathrm{g})$} \\
\hline $\begin{array}{l}\text { Protein }\left(\alpha-\mathrm{NH}_{2} \mathrm{mmol}\right. \\
\times \text { 102) }\end{array}$ & 0.33 & 0.37 & 0.31 & 0.35 \\
\hline Carbohydrate & 0.14 & 0.15 & 0.11 & 0.15 \\
\hline Lipid & 0.08 & 0.06 & 0.13 & 0.09 \\
\hline \multicolumn{5}{|c|}{$\begin{array}{l}\text { Diaminopimelic acid concentration } \\
\text { (DAP, mg/g particulate } \\
\text { dry matter) }\end{array}$} \\
\hline $\begin{array}{l}\text { Effluent particulate } \\
\text { matter }\end{array}$ & $8 \cdot 36$ & $7 \cdot 72$ & 5.05 & $7 \cdot 22$ \\
\hline $\begin{array}{l}\text { Effluent solution, } \\
\text { diaminopimelic acid } \\
\text { output }(\mathrm{g} / \mathrm{mol} \text { VFA) }\end{array}$ & 0.31 & 0.32 & 0.44 & $0 \cdot 20$ \\
\hline \multicolumn{5}{|l|}{ Microbial counts $(/ \mathrm{ml})^{*}$} \\
\hline Effiuent: Bacteria & 8 & 9 & 9 & 7 \\
\hline Protozoa & 4 & 3 & 14 & 0 \\
\hline $\begin{array}{l}\text { Reaction } \\
\text { mixture }\end{array}$ & & & & \\
\hline (last day): Bacteria & - & - & 6 & 4 \\
\hline Washings Protozoa & 一 & 一 & 138 & 16 \\
\hline (last day): Bacteria & - & - & $\begin{array}{r}17 \\
280\end{array}$ & 14 \\
\hline
\end{tabular}

A, mean values for vessel I, days $16-20$ and vessel 2 , days $26-30$;

$B$, mean values for vessel I, days $26-30$ and vessel 2 , days $16-20$.

* Bacterial count $\times 10^{10}$, protozoal count $\times 10^{2}$.

degradation at low dilution rates. The concentration of DAP in particulate matter at approximately $8 \mathrm{mg} / \mathrm{g}$ were the highest that we have ever observed.

The microbial counts (Table 5) showed that the protozoal population could survive when an inert matrix and soluble food is used, provided that the dilution rates are kept low. Comparison with Expt I suggests that the provision of natural nutrients such as found in soluble extracts of hay may also be necessary. The number of counted micro-organisms per unit weight of DAP was low at low dilution rates $\left(4 \times 10^{12} / \mathrm{mg}\right)$ and increased to $7 \times 10^{12} / \mathrm{mg}$ at the highest dilution rate. The value of $4 \times \mathrm{IO}^{12}$ bacteria/mg DAP was lower than the value of $5 \times 10^{12} / \mathrm{mg}$ obtained with soluble substrate in the earlier experiment or the mean value of $9 \times 1 \mathrm{I}^{12} / \mathrm{mg}$ obtained in experiments with solid substrates.

At the end of the experiment the bags with the undigested solids were removed from the vessels, allowed to drain and then each was washed three times with $10 \mathrm{ml}$ artificial saliva and squeezed to remove as much of the liquid as possible. Thus, in addition to the effluent collected during the last day, it was possible to analyse the free liquid in the reaction vessel, the liquid phase that was associated with the solid (the washings) and the liquid phase that was closely associated with the solid. The results are summarized in Table 6. Although the 
Table 6. Amounts and distribution of liquid and bacterial matter diaminopimelic acid $(D A P)$ in the reaction vessels and the specific output of these two components

(The volume of contents of the vessels up to the overflow was $960 \mathrm{ml}$ (1035-75 $\mathrm{ml}$ for moving cage etc.))

$\begin{array}{lrr}\text { Vessel no. ... } & \text { I } & 2 \\ \text { Liquid } & & \\ \text { In the vessel (ml) } & 600 & 615 \\ \text { Free liquid (compartment I) } & 140 & 124 \\ \text { Associated liquid* (compartment 2) } & 25 & 23 \\ \text { Liquid in solid † (compartment 3) } & 765 & 762 \\ \text { Total } & 440 & 1400 \\ \text { Output (ml/d) } & & \\ \text { DAP } & & \\ \text { In the vessel (mg) } & 15.6 & 7 \cdot 2 \\ \text { Free liquid } & 18 \cdot 1 & 7.3 \\ \text { Associated liquid } & 5 \cdot 1 & 4.0 \\ \text { Solid } & 38.8 & 18.5 \\ \text { Total } & 11.5 & 16.4 \\ \text { Output (mg/d) } & 0.29 & 0.89 \\ \text { Specific output/d } & & \end{array}$

DM, dry matter.

* Calculated from the expression: volume $=0.70 b w$, where $b$ is the specific PEG exclusion volume, $w$ is DM of the solid matrix.

$\dagger$ (Total washings + liquid in washed solid) - (volume of buffer solution used + volume of compartment 3.)

volume of reaction mixture up to the overflow was $960 \mathrm{ml}$, the true volume of liquid (sum of all the recovered volumes) was $760 \mathrm{ml}$. This means that, apart from the 'head-space' of gas, there is a lot of trapped gas and that the dilution rates must be greater than estimated from the measurements of volume of reaction mixture during the experiment. The dilution rates are even greater when one considers the free liquid only.

The analyses showed that the distribution of bacterial matter between the free liquid and the solid with its associated liquid, favoured the latter $(60 \%$ of total in the vessel). The concentrations of DAP in the effluent were similar to those found in free liquid, but they were much greater in the solid and in the liquid that was associated with the solid (five to seven times greater).

\section{Expt 3. Use of soluble food: comparison of continuous infusion and of rapid injection}

Although the input of soluble food was the same during the first $15 \mathrm{~d}$ of this experiment, the production of methane was greater during that period with continuous feeding (vessel no. I) than when the concentrated solution of food was injected in the morning (vessel no. 2). However, in due course methane production in vessel no. 2 increased to a value that was similar to that in vessel no. I (see Table 7). The total VFA production was similar in the two vessels, but the injection of food resulted in decreased production of acetic acid and a marked increase in the production of propionic acid. The output of particulate DM was considerably smaller in vessel no. 2 than in vessel no. r. This agreed with other measurements (protein, carbohydrate) and although the single injection of soluble food resulted in a greater output of soluble substances, these outputs were small compared with the inputs of food. The concentrations of carbohydrates in the reaction vessels were determined at frequent intervals on several consecutive days. The concentration of carbohydrate decreased very rapidly in vessel no. 2 (mean residence time of carbohydrate was $0.6 \mathrm{~h}$ compared with mean residence time of liquid of $20 \mathrm{~h}$ ). Clearly, the dilution of the reaction mixture could account for only a small proportion of the disappearance of carbohydrate and we must conclude that most of the carbohydrate injected was fermented. 
Table 7. Fermentation of soluble food in Rumen Simulation Technique (Rusitec) in presence of an inert matrix of undigested hay; comparison of the effect of continuous infusion of food and a single daily injection

(Mean values for days 17-22 or duplicate analyses of bulked samples)

\begin{tabular}{|c|c|c|}
\hline Vessel no. ... & $\begin{array}{c}\mathrm{I} \\
\text { (continuous } \\
\text { infusion } 9.1 \mathrm{~g} / \mathrm{d} \text { ) }\end{array}$ & $\begin{array}{c}2 \\
\text { (daily injection } \\
9.5 \mathrm{~g} / \mathrm{d} \text { ) }\end{array}$ \\
\hline \multicolumn{3}{|l|}{ Gases $(\mathrm{mmol} / \mathrm{d})$} \\
\hline Methane & $20 \cdot 3$ & $19 \cdot 6$ \\
\hline Carbon dioxide & $30 \cdot I$ & $31 \cdot 9$ \\
\hline \multicolumn{3}{|c|}{ Volatile fatty acids (mmol/d) } \\
\hline Acetic & $36 \cdot 3$ & $26 \cdot 3$ \\
\hline Propionic & $4 \cdot 3$ & $I I \cdot I$ \\
\hline Butyric & 6.8 & $7 \cdot 0$ \\
\hline $\mathrm{C}_{6}$ acids & $2 \cdot I$ & $1 \cdot 3$ \\
\hline Lactic acid (mmol/d) & 0.06 & 0.23 \\
\hline \multicolumn{3}{|l|}{ Particulate matter (g/d) } \\
\hline DM & $1 \cdot 52$ & 0.23 \\
\hline Protein ${ }^{*}$ & 0.55 & 0.09 \\
\hline Carbohydrate & 0.24 & 0.10 \\
\hline \multicolumn{3}{|l|}{ Solution $(\mathrm{mg} / \mathrm{d})$} \\
\hline Protein (direct) & 7 & 3 \\
\hline Protein (hydrolysis) & 43 & $7 \mathrm{I}$ \\
\hline Carbohydrate & 40 & 460 \\
\hline
\end{tabular}

Table 8. Distribution of liquid and bacterial matter and concentration of microbial matter in the vessels during continuous infusion $(C)$ and single injection $(S)$ of soluble food in Rumen Simulation Technique (Rusitec)

\begin{tabular}{|c|c|c|c|c|c|c|c|c|}
\hline \multirow[b]{2}{*}{ Amounts } & \multicolumn{2}{|c|}{$\begin{array}{c}\text { Effluent } \\
(/ \mathrm{d})\end{array}$} & \multicolumn{2}{|c|}{$\begin{array}{l}\text { Reaction } \\
\text { mixture }\end{array}$} & \multicolumn{2}{|c|}{$\begin{array}{l}\text { Liquid } \\
\text { associated } \\
\text { with solid }\end{array}$} & \multicolumn{2}{|c|}{ Solid } \\
\hline & $\mathrm{C}$ & $S$ & $\mathrm{C}$ & $\mathbf{S}$ & C & $\mathbf{S}$ & C & $\mathbf{S}$ \\
\hline $\begin{array}{l}\text { Liquid (ml) } \\
\text { DM (g) } \\
\alpha \text {-amino-nitrogen } \\
\text { (mmol) }\end{array}$ & $\begin{array}{l}585 \\
1 \cdot 55 \\
5 \cdot 4\end{array}$ & $\begin{array}{l}605 \\
0.23 \\
0.8\end{array}$ & $\begin{array}{l}610 \\
1 \cdot 97 \\
6 \cdot 4\end{array}$ & $\begin{array}{l}495 \\
0.56 \\
0.4\end{array}$ & $\begin{array}{l}96 \\
3 \cdot 46 \\
8 \cdot 9\end{array}$ & $\begin{array}{l}145 \\
11 \cdot 18 \\
46 \cdot 3\end{array}$ & $\begin{array}{l}24 \\
9 \cdot 68 \\
7 \cdot 6\end{array}$ & $\begin{array}{l}27 \\
11 \cdot 23 \\
22 \cdot 7\end{array}$ \\
\hline $\begin{array}{l}\text { DAP (mg) } \\
\text { AEP-phosphorus } \\
(\mu \mathrm{g})\end{array}$ & $\begin{array}{c}8 \cdot 8 \\
236\end{array}$ & $\begin{array}{l}0.4 \\
46\end{array}$ & $\begin{array}{l}9 \cdot 0 \\
323\end{array}$ & $\begin{array}{c}0.3 \\
32\end{array}$ & $\begin{array}{l}6 \cdot 6 \\
225\end{array}$ & $\begin{array}{l}59 \cdot 3 \\
597\end{array}$ & $\begin{array}{l}4^{\cdot 0} \\
33^{\circ}\end{array}$ & $\begin{array}{l}27 \cdot 2 \\
80\end{array}$ \\
\hline $\begin{array}{l}\text { Concentrations } \\
\alpha-\mathrm{NH}_{2}(\mathrm{mmol} / \mathrm{d}) \\
\operatorname{DAP}(\mathrm{mg} / \mathrm{l}) \\
\text { AEP-P }(\mathrm{mg} / \mathrm{l})\end{array}$ & $\begin{array}{r}9.4 \\
14.3 \\
0.5\end{array}$ & $\begin{array}{l}1.5 \\
0.8 \\
0.1\end{array}$ & $\begin{array}{r}10.5 \\
14.7 \\
0.5\end{array}$ & $\begin{array}{l}0.9 \\
0.5 \\
0.1\end{array}$ & $\begin{array}{l}94 \\
70 \\
2 \cdot 3\end{array}$ & $\begin{array}{l}301 \\
417 \\
3.9\end{array}$ & $\begin{array}{l}318 \\
167 \\
1.4\end{array}$ & $\begin{array}{r}844 \\
1007 \\
3.0\end{array}$ \\
\hline
\end{tabular}

DM, dry matter; DAP, diaminopimelic acid; AEP, aminoethylphosphonic acid.

Although the output of microbial matter in the effluent was small when the soluble food was injected, washing of the solid matrix resulted in removal of considerable amounts of particulate matter (see Table 8). This material contained approximately $400 \mathrm{~g}$ protein $/ \mathrm{kg}$ and therefore could not be derived from undigested hay residue. The washings and the washed residues in vessel no. 2 contained large amounts of DAP. During the last io $d$ of the experiment, the outputs of DAP in vessel nos. I and 2 were $80 . \mathrm{I}$ and $4.3 \mathrm{mg}$ in the effluent, while at the end of the experiment the solid and the associated liquid phase 
(washings) contained 10.6 and $86.5 \mathrm{mg}$ DAP in vessels nos. I and 2 respectively. If the large amounts of DAP in the solid digesta of vessel no. 2 are due to accumulation over some Io d, then the average production of DAP is the same in vessel nos. I and $2(7.6 \mathrm{mg} / \mathrm{d})$. Since the solid matrix was not examined until the end of experiment, it is difficult to tell what is the nature of this accumulation.

The concentrations of $\alpha-\mathrm{NH}_{2}$ group (a measure of protein), DAP and aminoethylphosphonic acid (AEP) (bacterial and protozoal markers) are also given in Table 8. Clearly, the concentrations of all components were similar in the effluent and the reaction mixtures, although they were considerably smaller in vessel no. 2 than in vessel no. I. However, in both vessels, the concentrations of these components were greater in the washings and considerably greater in the washed residue.

The hydrogen recoveries in Expts I, 2 and 3 were calculated as described by Marty \& Demeyer (1973). The recoveries were high (over $100 \%$ ) in Expts I and 3 and they were good at low and intermediate dilution rates in Expt 2 (93-97\%). However, at high dilution rate in Expt 2 the recovery of hydrogen was very low (79\%). The low production of methane under these conditions agreed with an increased output of propionic acid, but this is accounted for in the calculations.

\section{DISCUSSION}

Although rumen fermentation can be simulated more closely when the reaction mixture contains a solid phase, and although the feeding procedure in Rusitec is straightforward, for some purposes (e.g. studying the effect of $\mathrm{O}_{2}$ ) it would be better if the incubations were made without opening the reaction vessels. It is not difficult to devise a balanced soluble diet, but the choice of a suitable solid matrix required more consideration. Ideally, the matrix should resemble the semi-solid digesta that is normally present in the rumen and should not be digestible. We have observed in numerous experiments with Rusitec that although $500-600 \mathrm{~g} \mathrm{DM}$ of the roughage rations $/ \mathrm{kg}$ are digested, the residual particles tend to retain their structure. In other words, exhaustive digestion of hay would leave some indigestible residue that might act as an inert, but acceptable matrix.

The indigestible residue of hay had a somewhat lower content of cellulose than the original hay $(310 \mathrm{~g} / \mathrm{kg}$ compared with $350 \mathrm{~g} / \mathrm{kg}$ for hay). This indigestible fibrous plant material was probably heavily lignified, and it seemed that if such a lignified material would act as a suitable matrix, the procedure would be greatly simplified if we could use a more direct source of lignified material without the necessity of removing digestible material by prolonged incubation. Wood shavings appeared to be the best choice.

The results obtained in Expts $I$ and 2 indicated that under the conditions used, a heavilylignified inert matrix cannot successfully replace the matrix provided by regular addition of solid food. It was impossible to maintain the output of protozoa in the effluent except when small amounts of hay were still being digested. The reduction of dilution rate to values that would allow the generation of protozoa to keep up with the wash-out and reinoculation with sufficient protozoa to give the same numbers as at the start of the experiment, led to fast disappearance of protozoa in the effluent from all vessels. A dilution rate of $0.43 / \mathrm{d}$ would give a mean residence time approximately $2.3 \mathrm{~d}$. This is longer than the known generation time of protozoa ( $\mathrm{I} \cdot 5-2 \cdot 0 \mathrm{~d}$ ). Thus, even if the lignified matrix was not capable of sequestrating protozoa, it is unlikely that they would be washed out and the results would suggest that either the soluble nutrients provided could not support a growth of protozoa in the liquid phase or that the dilution rate was greater than the nominal dilution rate. Some protozoa were found in the reaction mixture and in the washings.

The soluble substrate resulted in a good bacterial growth, which increased when the 


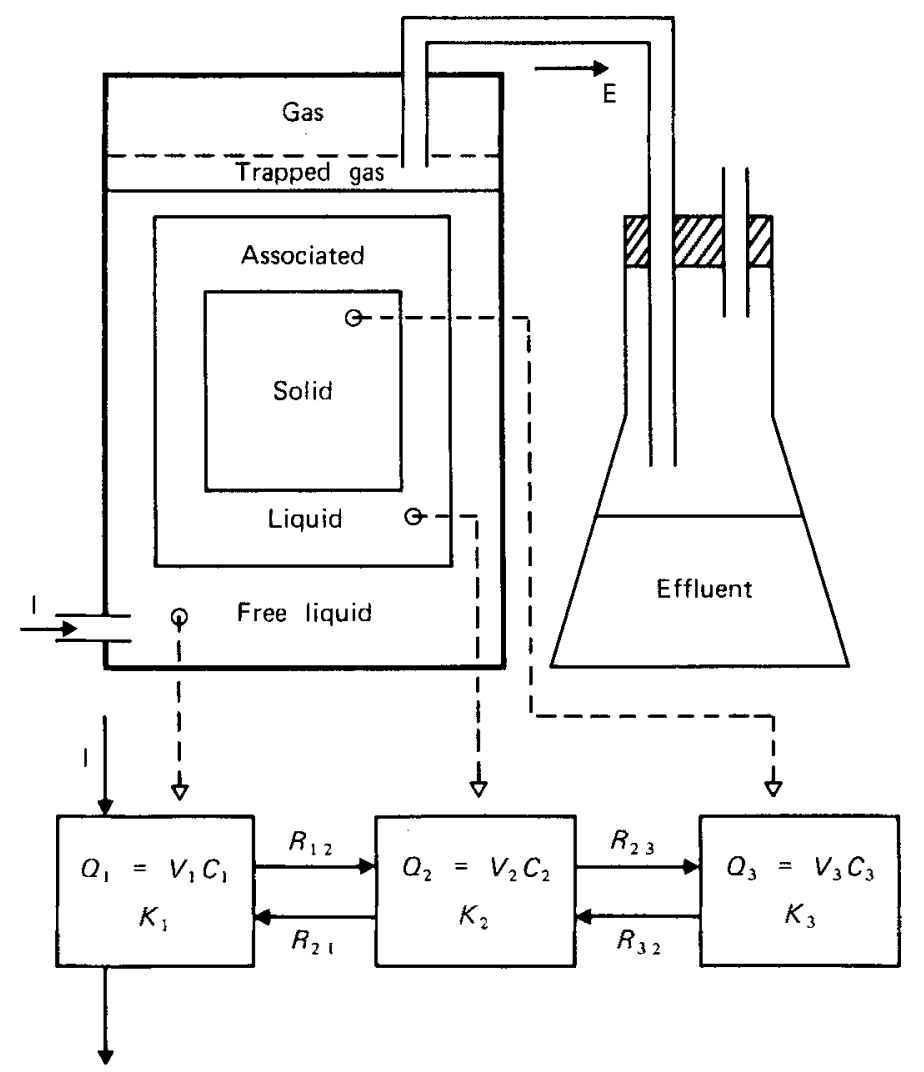

Fig. I. Schematic representation of Rumen Simulation Technique (Rusitec) to explain the proposed compartmentation of the reaction vessels in gas, liquid and solid phases. The 'trapped' gas is distributed throughout the reaction mixture and solid phase (in addition to the headspace gas). The 'associated' liquid and particles can be washed out by the usual rinsing procedures employed (compartment 2), while the liquid and the particles that cannot be readily removed from the solid phase constitute compartment 3. The quantities used in the calculations are defined in the Appendix. In any of the compartments, $Q$ is the amount of a substance, $C$ is its concentration and $K$ is its specific rate of formation, $V$ is the volume and the quantities $R$ give specific flow-rates.

protozoal numbers declined. The solid matrix at the end of the experiment contained bacterial population, which increased when the protozoal numbers declined. The solid matrix contained bacterial matter and the amounts in the indigestible residue of the hay were similar to those found in hay incubated for $2 \mathrm{~d}$ only (normal feeding procedure). Although the content of bacterial matter in wood shavings was considerably smaller than in hay, there was sufficient to suggest that bacteria could be sequestrated.

The nominal dilution rate can be calculated from the outflow of liquid and the volume of liquid in the reaction vessel. The results showed that the volume of liquid in the vessel is considerably less than the volume up to the overflow and therefore the dilution rates calculated in this manner may not be very meaningful.

We tried to gain more insight into the flows within the reaction vessels by considering a three-compartment model of this simplified version of Rusitec (Fig. I). It is assumed that the free liquid reaction mixture constitutes the main compartment (compartment 1 ). The liquid that is associated with the solid, and which can be removed by vigorous washing with artificial saliva constitutes the second compartment (compartment 2 ). The liquid in the 
Table 9. Flows of liquid and the dilution rates within the three compartments of Rumen Simulation Technique (Rusitec)

(The values in parentheses are calculated by assuming that the specific rate of synthesis of DAP is proportional to the outflow*)



\begin{tabular}{|c|c|c|}
\hline & \multirow{3}{*}{$\begin{array}{c}3 \\
\text { I } \\
\text { (infusion) }\end{array}$} \\
\hline$\stackrel{1}{\text { (half flow) }}$ & (double flow) & \\
\hline 0.4 & $1 \cdot 4$ & \\
\hline 600 & 615 & 610 \\
\hline 140 & 124 & 96 \\
\hline 25 & 23 & 24 \\
\hline 765 & 762 & 730 \\
\hline 440 & 1400 & 585 \\
\hline $66(65)$ & 313 (IOI) & $88(58)$ \\
\hline $20(29)$ & 3 I (6) & $18(13)$ \\
\hline $0.78(0.73)$ & $2 \cdot 62(2.44)$ & I. I2 (I.05) \\
\hline $0.61(0.67)$ & $1.96(0.86)$ & I. $10(0.74)$ \\
\hline $0.80(1 \cdot 16)$ & $1 \cdot 35(0.26)$ & $0.64(0.54)$ \\
\hline
\end{tabular}

Table I0. Synthesis and flows of bacterial marker (diaminopimelic acid; DAP) in various compartments of Rumen Simulation Technique (Rusitec)

(The values in parentheses are calculated by assuming that the specific rate of synthesis of DAP is proportional to the rate of outflow*)

\begin{tabular}{|c|c|c|c|}
\hline \multirow{2}{*}{$\begin{array}{l}\text { Expt } \quad \ldots \\
\text { Vessel no. }\end{array}$} & \multicolumn{2}{|c|}{2} & \multirow{2}{*}{$\begin{array}{c}3 \\
\text { I } \\
\text { (infusion) }\end{array}$} \\
\hline & $\begin{array}{c}I \\
\text { (half flow) }\end{array}$ & $\stackrel{2}{\text { (double flow) }}$ & \\
\hline Food input $(\mathrm{g} / \mathrm{d})$ & $11 \cdot 9$ & $12 \cdot 0$ & $9 \cdot 1$ \\
\hline \multicolumn{4}{|l|}{$\begin{array}{l}\text { Net synthesis of } \\
\text { DAP (mg/d) }\end{array}$} \\
\hline Compartment I & $4 \cdot 7(4 \cdot 9)$ & $6 \cdot 4(1 \mathrm{II} \cdot 6)$ & $4 \cdot 0(5 \cdot 9)$ \\
\hline Compartment 2 & $5.4(4 \cdot 5)$ & $6 \cdot 5(4 \cdot 1)$ & $3 \cdot 0(2 \cdot 6)$ \\
\hline Compartment 3 & $I \cdot 5(2 \cdot 2)$ & $3.6(0.6)$ & $I \cdot 8(0.6)$ \\
\hline Total outflow & $11 \cdot 6$ & 16.5 & \\
\hline \multicolumn{4}{|c|}{ Flows of DAP $(\mathrm{mg} / \mathrm{d})$} \\
\hline$I \rightarrow 2$ & $I \cdot 7(I \cdot 7)$ & $2.5(1 \cdot 2)$ & $1 \cdot 4(0.8)$ \\
\hline $2 \rightarrow I$ & $8 \cdot 5(8 \cdot 4)$ & $12.5(5.9)$ & $6 \cdot I(4 \cdot 0)$ \\
\hline $2 \rightarrow 3$ & $2 \cdot 6(3 \cdot 8)$ & $1.8(0.3)$ & $1 \cdot 3(0 \cdot 4)$ \\
\hline $3 \rightarrow 2$ & $4 \cdot 2(6 \cdot 0)$ & $5.4(0.9)$ & $3 \cdot I(I \cdot 0)$ \\
\hline \multicolumn{4}{|l|}{$\begin{array}{l}\text { Mean residence time } \\
\text { of DAP (d) } \dagger\end{array}$} \\
\hline Compartment 1 & $I \cdot 2(1 \cdot 2)$ & $0.4(0.4)$ & $0.9(0.9)$ \\
\hline Compartment 2 & $I \cdot 6(1 \cdot 4)$ & $0.5(1.2)$ & $0.9(1 \cdot 5)$ \\
\hline Compartment 3 & $1 \cdot 2(0.9)$ & $0.7(4.4)$ & $1 \cdot 3(3.9)$ \\
\hline
\end{tabular}

* See Appendix.

$\dagger$ Reciprocal of specific outflow rate. 


\section{J. W. CzerkawsKi and Grace BreCKenRidge}

third compartment (compartment 3 ) is so closely associated with the solid matrix that the micro-organisms trapped therein cannot be readily washed out. Using the procedure outlined in the Appendix and the values given in Tables 6 and 8 , it was possible to calculate the measurements that define the three-compartment model of Rusitec. The results of these calculations are given in Tables 9 and $\mathrm{I} 0$.

It can be seen that the flow of liquid between compartments I and 2 was approximately one-sixth of the inflow and that the flow between compartments 2 and 3 was approximately one-thirtieth the inflow into the system. The dilution rates in compartment I (total outflow/ volume) were generally considerably greater than the nominal dilution rate for the system (outflow from the system/volume up to overflow). The rates were similar in all three compartments when the inflow of liquid into the system was low, but when the inflow was increased, the dilution rates decreased with the 'depth' of compartments.

Thus, the nominal dilution rates of $0.7-0.8 / \mathrm{g}$ used in many experiments with Rusitec may be nearer the values $\mathrm{I} \cdot 3-\mathrm{I} \cdot 5 / \mathrm{d}$ and this is considered to be the normal range for the rumen. In the earlier experiments (Czerkawski \& Breckenridge, 1977), when the nominal dilution rates were $0.33,0.59,0.8 \mathrm{I}$ and 0.95 , the output of end-products of fermentation was maximal at the intermediate rate of approximately $0.75 / \mathrm{d}$, which again corresponds to a true dilution rate of $1 \cdot 4 / \mathrm{d}$. The dilution rate of $2.55 / \mathrm{d}$ on the last day of the experiment is too fast for a successful replication of protozoa and it is not surprising that no protozoa could be found in the effluent. However, protozoa were found in the reaction mixture, small numbers in the free liquid, compartment $\mathbf{1}$, and larger numbers in the liquid that was associated with the solid. An estimate of protozoa in the solid matrix as AEP (compartment 3 not reported here) showed that the concentration of protozoa in this compartment might be even greater than in compartment 2.

The DAP content of the three compartments was used to calculate the distribution, flow and synthesis of bacterial matter (Table I0). The daily synthesis of DAP appeared to be similar in compartments $\mathrm{I}$ (reaction mixture) and 2 (liquid associated with the solid) but it was usually lower in compartment 3 (liquid trapped within the solid). The flows of DAP were always greater in the direction compartments $3 \rightarrow$ compartment $I$, i.e. towards the incoming food than in the opposite direction. With higher nominal dilution rates the mean residence time of DAP increased with the 'depth' of the compartment, i.e. the extent of sequestration increased.

The calculation for the vessel in which the food was injected once per day, showed that some of the flows, dilution rates and residence times were abnormally high or low. For instance, such calculations imply that the flow between compartments I and 2 (I I I $5 \mathrm{ml} / \mathrm{d}$ ) is greater than the outflow from the system $(585 \mathrm{ml} / \mathrm{d})$. No meaning can be attached to such values, because the calculations made in the Appendix referred specifically to steadystate conditions. However, they show the danger of indiscriminate application of mathematical procedures.

The calculations in the Appendix were based on four assumptions. The first three assumptions are quite reasonable; the idea that there is no direct flow between compartments $I$ and 3 is inherent in the model and since the solid matrix is not digested, the volumes of compartments are constant. There was no drift in the output of DAP from the system and therefore the amount of DAP in various compartments must remain constant. The fourth assumption that the specific rate of synthesis of DAP is the same in all three compartments is an over-simplification. This assumption was made in the first place to show in a simple manner the procedure used in the calculations. If it is assumed that the specific rates of synthesis of DAP in each compartment are proportional to total outflow from the relevant compartment, further calculations can be made (see Appendix). This results in another set of values to describe the model and these are given in parentheses in Tables 9 and Io. 
At low nominal dilution rate the flow of liquid or the actual dilution rates in each compartment were not radically different whatever the assumption about the specific rates of synthesis of DAP (Expt 2, vessel I). However, the values in the two sets diverged at higher nominal dilution rate (Table 9). The differences between the two sets of values were also apparent with net synthesis, flow and sequestration of DAP (see Table 10). Again the differences increased with increasing nominal dilution rates. It is interesting to note the low net synthesis and the long residence time of DAP in compartment 3 at high dilution rate of the system. This may illustrate the ability of some slow-growing micro-organisms to survive at high dilution rate in a heterogeneous system.

The assumption that the specific rate of synthesis of DAP is the same in all compartments gave a semiquantitative description of the system. It seems that if the specific rates are proportional to the outflows, the model becomes more realistic. However, neither procedure took account of the water phase in the micro-organisms (about $80 \%$ ). It can be shown that in compartment I the volume occupied by the micro-organisms is not more than $2 \%$ of total compartment volume and thus can be ignored. In compartments 2 and 3 microbial water could account for 10 and $18 \%$ of total water respectively. These quantities are not small and in fact could account for a considerable proportion of water flowing between compartments 2 and 3. Clearly, microbial water will have to be taken into account in future work.

The use of soluble food and an inert solid matrix required a three-compartment model. It can be shown that when normal solid food is used, the model would contain four or five compartments, and since some of these are removed and replaced by new ones and since the size of some of these compartments will change throughout the day, the problem becomes very difficult. The situation in the rumen must be even more complicated than in the Rusitec that is given solid food and yet a great deal of quantitative studies in ruminology involve the assumption that the rumen is a one-compartment system.

The authors are grateful to Mrs C. Faulds for expert analytical assistance.

\section{APPENDIX}

\section{Definition of quantities}

$Q_{i}$, amount of DAP in compartment $i(\mathrm{mg})$;

$V_{i}$, volume of compartment $i(\mathrm{ml})$;

$K_{i}$, specific net rate of synthesis of DAP in compartment $i$ (e.g. net synthesis in compartment ( 1$\left.)=K_{1} Q_{1} \mathrm{mg} / \mathrm{d}\right)$;

$R_{i j}$, specific flow rate from compartment $i$ to $j$,

(e.g. flow of liquid from compartment $\mathrm{I}$ to $2=R_{12} . V_{1}$ );

$E$, outflow of DAP from the system $(\mathrm{mg} / \mathrm{d})$.

\section{Assumptions}

(a) The flows are as defined in Fig. I, i.e. there is no direct flow from compartment 1 to 3.

(b) The volumes of compartments remain constant, therefore $R_{i j} V_{i}=R_{j i} V_{i}$.

(c) At steady-state the amount of DAP in each compartment remains constant, i.e.

$$
d Q / d t=0 \text {. }
$$

(d) The specific rate of synthesis of DAP is the same in all three compartments (see subsequent calculations). 
At steady-state (assumption $c$ )

\section{Calculation of flows}

$$
\begin{gathered}
\mathrm{d} Q_{1} / d t=R_{21} Q_{2}-R_{12} Q_{1}+K_{1} Q_{1}-E=0, \\
\mathrm{~d} Q_{2} / d t=R_{12} Q_{1}-R_{21} Q_{2}+R_{32} Q_{3}-R_{23} Q_{2}+K_{2} Q_{2}=0, \\
d Q_{3} / d t=R_{23} Q_{2}-R_{32} Q_{3}+K_{3} Q_{3}=0 .
\end{gathered}
$$

By assumption $b$, we have:

$$
\begin{aligned}
& V_{1} R_{12}=V_{2} R_{21}, \\
& V_{2} R_{23}=V_{3} R_{32} .
\end{aligned}
$$

The outflow from the system must be equal to total synthesis and so we have:

$$
E=K_{1} Q_{1}+K_{2} Q_{2}+K_{3} Q_{3}
$$

Substituting equation no. 4 in equation no. $I$ and rearranging, we get:

$$
R_{21}=\frac{E / Q_{1}-K_{1}}{\left(Q_{2} / Q_{1}-V_{2} / V_{1}\right)}
$$

Substituting equation no. 5 in equation no. 3 and rearranging, we get:

$$
R_{23}=\frac{K_{3}}{\left(V_{2} / V_{3}-Q_{2} / Q_{3}\right)} .
$$

If the volumes of liquid, the amounts of DAP and the specific rates of synthesis are known, all the specific flow rates $R$ can be calculated from equations nos. 7, 8, 4 and 5 .

The volumes of compartments $I$ and 2 can be measured directly, but the volume of compartment 3 must be estimated. This can be done by considering the exclusion volume of polyethylene glycol (Czerkawski \& Breckenridge, 1969) in the solid matrix. This turns out to be 2.5 times the numerical value of dry weight $(\mathrm{g})$ of the solid matrix.

Finally, by assumption $d$, we can calculate $K$, from equation no. 6 . Knowing the values of $R$, the flows of liquid and DAP between the compartments can be calculated.

If the specific rates of synthesis of DAP are proportional to the total outflows from each compartment, then we have three additional equations:

$$
\begin{gathered}
K_{1}=\alpha\left(R_{12}+E / Q_{1}\right), \\
K_{2}=\alpha\left(R_{21}+R_{23}\right), \\
K_{3}=\propto R_{32},
\end{gathered}
$$

where $\alpha$ is the proprotionality constant and $E / Q_{1}$ is the specific flow from compartment I (effluent). Although the calculations are more involved, it is possible to obtain all the values to describe the model in a quantitative manner.

The value of $\alpha$ is obtained by substituting $K_{3}$ from equation no. I I into equation no. 8 and eliminating $R_{23}$ and $R_{32}$ using equation no. 5. This gives:

$$
\alpha=\mathrm{I}-\frac{C_{2}}{C_{3}}
$$

where

$$
C_{2}=\frac{Q_{2}}{V_{2}}, C_{3}=\frac{Q_{3}}{V_{3}} \text { (concentrations). }
$$

It is possible to calculate $R_{12}$ and $R_{21}$ by eliminating $K_{1}$ between equations nos. 7 and 9 
and clearly $K_{1}$ can be calculated using equation no. 9. Since $K_{1}$ is known now, elimination of $K_{2}$ and $R_{23}$ from equations nos. 6,8 and Io gives $K_{3}$ in terms of known quantities. It is not difficult to calculate $R_{23}$ and $R_{32}$ from equations nos. 5 and I I and the known value of $K_{3}$. Finally $K_{2}$ is calculated using equation no. Io.

The specific flow rates and the specific rates of synthesis of DAP can be expressed in terms of concentrations of the marker in each compartment (equation nos. 13-17), where $C_{1}=Q_{1} / V_{1}$.

$$
\begin{gathered}
R_{12}=\frac{E}{V_{1}\left(C_{3}-C_{1}\right)} \\
R_{23}=\frac{E\left(C_{2}^{2}-C_{1} C_{3}\right)}{V_{2}\left(C_{3}-C_{1}\right)\left(C_{3}{ }^{2}-C_{2}{ }^{2}\right)} \\
K_{1}=\frac{E\left(C_{3}-C_{2}\right)}{Q_{1}\left(C_{3}-C_{1}\right)} \\
K_{2}=\frac{E}{V_{2}\left(C_{3}+C_{2}\right)} \\
K_{3}=\frac{E\left(C_{2}^{2}-C_{1} C_{3}\right)}{Q_{3}\left(C_{3}-C_{1}\right)\left(C_{3}+C_{2}\right)}
\end{gathered}
$$

\section{REFERENCES}

Czerkawski, J. W. (1976). J. Sci. Fd Agric. 27, 323.

Czerkawski, J. W. \& Breckenridge, G. (I969). Br. J. Nutr. 23, 559.

Czerkawski, J. W. \& Breckenridge, G. (1977). Br. J. Nutr. 38, 37 I.

Czerkawski, J. W. \& Breckenridge, G. (1979). Br. J. Nutr. 42, 217.

Latham, M. J., Brooker, B. E., Pettipher, G. L. \& Harris, P. J. (1978). Appl. Environ. Microbiol. 35, I 166. McDougall, E. I. (1948). Biochem. J. 43, 99.

Marty, R. J. \& Demeyer, D. I. (1973). Br. J. Nutr. 30, 369.

Orpin, C. G. \& Letcher, A. J. (1978). J. gen. Microbiol. 106, 33. 